This is an electronic version of an article published in Bencze, J. L. (2009). An eloquent and argumentative treatise on the history, philosophy and sociology of science for school science. [Review of the book Towards scientific literacy: A teachers' guide to the history, philosophy and sociology of science, by D. Hodson]. Canadian Journal of Science, Mathematics and Technology Education, 9(4), 276-288. Cognition and Instruction is available online at: www.tandfonline.com<http://www.tandfonline.com/> with http://www.tandfonline.com/openurl?genre=article\&issn=1492-6156\&volume=9\&issue=4\&spage=276

Please note that tables/figures that are referred to in this article are not available on the post-print version. For the full article with tables/figures please click on the link above.

\title{
An Eloquent and Argumentative Treatise on the History, Philosophy and Sociology of Science for School Science
}

[Review of Hodson, D. (2008). Towards scientific literacy: A teachers' guide to the history, philosophy and sociology of science. Rotterdam: Sense. For CJSMTE.]

\section{John Lawrence Bencze}

OISE, University of Toronto

\section{Introduction}

In the typical classroom, instruction has focused almost exclusively on the wellestablished products of science and cookbook approaches to laboratory exercises, using authoritarian teaching modes (Bell, 2006, p. 430).

While youth need access to the intellectual riches of our societies, a nearly exclusive focus on societal achievements in the sciences can be highly problematic for them. Collins, Osborne, Ratcliffe, Millar and Duschl (2001) state, for example, that an "overemphasis on 'what we know' at the expense of 'how we know' results in a science education which too often leaves students only able to justify their beliefs by reference to the teacher as an authority" (p. 4). In other words, conditioned dependence on authorities may jeopardize students' potential autonomy in societal decision-making involving science and technology. As consumers of products and services generated using science and technology, for example, poor conceptions of the nature of knowledge generation and dissemination in these fields may limit the extent to which they can critically evaluate the merits of such products. This seems particularly crucial in societies where businessgenerated desires (e.g., via marketing) for products and services may be compromising the wellbeing of individuals, societies and environments (e.g., McMurtry, 1999).

For these and other reasons he describes and defends, educators - and, ultimately, students - can greatly benefit from Derek Hodson's book, Towards Scientific Literacy: A Teachers' Guide to the History, Philosophy and Sociology of Science (Sense, 2008). In 
this article, I summarize and analyze this book in the light of relevant published works and my own experiences as a student and science educator.

\section{About the Author}

A major consideration in choosing any author's book would, of course, pertain to the person's credibility in the subject of the writing. Professor Derek Hodson has excellent credentials in this regard. His career has been and continues to be so extensive and complex that it is hard to know where to start. In his book, he notes that, "[a]s a schoolboy in the 1950s I always looked forward to the frequently dull science lessons being enlivened by the stories about scientists that sprinkled the pages of science textbooks by E.J. Holmyard and F. Sherwood Taylor" (p. ix). Later, in his undergraduate years in chemistry, he took a comprehensive philosophy of science course and attended lectures about the history and philosophy of science. "Later still, as a student teacher at the University of Exeter, [he said that he] was privileged to study with the eminent historian of science, H.J.J. Winter, author of Eastern Science: An Outline of its Scope and Contribution" (p. ix).

Part of Professor Hodson's legitimacy for writing this book may stem from the fact that he has a Ph.D. in chemistry and has published several science articles from his work with titles like, "-Diazosulphones and related compounds from the base-induced cleavage of -diazo--ketosulphones." As he notes in his book, scientists often do not have welldeveloped declarative conceptions of their work (as is the case with people in most occupations). However, deep work in a field, such as chemistry, is likely to, at the least, provide a person with extensive tacit knowledge about that field (Polanyi, 1958). Tacit knowledge, in turn, can be linked to propositional knowledge - such as certain claims about science — and, thus, deepen the propositional knowledge. Judging from the extensive reference list in this book (789 references), Professor Hodson appears to have gained access to a considerable set of propositions about science. This may account for the richness of Professor Hodson's treatment of the complex subject matter in the history, philosophy and sociology of science (HPSS).

Immediately after obtaining his Ph.D. in chemistry, he began a career as a secondary science teacher - a field in which he worked until 1977, the year he accepted his first university faculty position (University of Wales). He has since worked as Lecturer or Professor in other universities in the United Kingdom, New Zealand, and Hong Kong. He is currently Adjunct Professor of Science Education at the University of Auckland, NZ.

Professor Hodson is an extremely prolific science education scholar, having published over 100 articles in refereed journals, 6 books (including this one) and 40 book chapters. His research and writing have spanned a great breadth of topic areas, including: computer assisted learning (educational technology), laboratory work, the history, philosophy, and sociology of science (nature of science), multicultural science education, antiracist education, gender issues in science education, science teacher education, the politicization (activist STSE Education) of science education and, most recently, scientists' conceptions of science and science education. Throughout this work, you will find that he has collaborated with colleagues, both locally and globally, and with graduate 
students and teachers. He also has published many sole-author articles and book chapters, sometimes being known as 'a great science education essayist.'

Finally, Professor Hodson also excels as a graduate course instructor and thesis supervisor. He initiated and conducted several graduate courses at OISE, University of Toronto, including the one on which this book is based. His courses always attract large numbers of students, as evidenced by the numerous thesis students he has supervised; that is, 16 M.A., 13 M.Ed. (by thesis), 42 M.Ed. (by course work \& dissertation), and 28 Ph.D. \& 3 Ed.D.

\section{Book Summary}

Professor Hodson's book is a substantial piece of writing. In ten chapters, using 102,950 words (210 pages) of text, numerous footnotes in each chapter, and 789 references, he provides an extremely readable, comprehensive and argumentative coverage of history, philosophy and sociology of science relevant to school science. To give readers a flavour for the nature of this book, I have prepared a summary of each chapter - as shown in Table 1. Readers may find this summary useful in reading my analyses, below.

\section{TABLE 1: CHAPTER OUTLINES}

\begin{tabular}{|l|l|}
\hline Title & Summary \\
\hline Chapter One & $\begin{array}{l}\text { In this initial chapter, Professor Hodson explores possible meanings } \\
\text { for the nebulous concept, scientific literacy. Acknowledging the } \\
\text { diversity of its meaning, he details and inquires into a historical series } \\
\text { of definitions of scientific literacy from the perspectives of various } \\
\text { 'stakeholders' - including those of scientists, business people, } \\
\text { parents, and students. In his treatment of science literacy, he devotes } \\
\text { considerable space to issues pertaining to language literacy - which } \\
\text { he notes is essential to use of science by scientists and non-scientists. } \\
\text { Philosophy and } \\
\text { Sociology of Science } \\
\text { (12,708 words) }\end{array}$ \\
$\begin{array}{l}\text { He follows this emphasis with discussion of and defenses for } \\
\text { education in HPSS as part of any citizen's scientific literacy. In the } \\
\text { end, he makes clear his intention to promote universal critical } \\
\text { scientific literacy - which, I should stress, would involve student } \\
\text { activism aimed at addressing important personal, social and } \\
\text { environmental issues relating to science and technology. Fundamental } \\
\text { to this position is his claim that the conduct and uses of science are } \\
\text { associated with issues of power and control. }\end{array}$ \\
\hline $\begin{array}{l}\text { EXPLORING } \\
\text { NATURE OF }\end{array}$ & $\begin{array}{l}\text { Arguably typical of an academic committed to constructivist } \\
\text { epistemological perspectives and pedagogical practices, Professor } \\
\text { Hodson precedes recommendations for HPSS education (reserved, } \\
\text { largely, to chapters 8-10) with a critical analysis of research methods } \\
\text { used to ascertain students' HPSS conceptions. As a constructivist, he }\end{array}$ \\
\hline
\end{tabular}




\begin{tabular}{|c|c|}
\hline $\begin{array}{l}\text { SCIENCE ISSUES } \\
\text { Students' Views and } \\
\text { Curriculum Images } \\
\text { (9,320 words) }\end{array}$ & $\begin{array}{l}\text { concludes that more qualitative, naturalistic research approaches are } \\
\text { best. Based on research and meta-study reports involving such } \\
\text { approaches, he concludes [perhaps despite uncertainties associated } \\
\text { with research methods] that “...there is ample evidence that many } \\
\text { students do leave school with a confused, confusing, deficient or } \\
\text { distorted view of the nature of science and the activities of practising } \\
\text { scientists" (p. 33). Although he problematizes the following position, } \\
\text { he discusses the idea that, ironically, education systems may not } \\
\text { seriously aim to educate all students to the best of their abilities. This } \\
\text { leads him to explore the ideas from future studies, which emphasize } \\
\text { that we must all act responsibly for a bright future. }\end{array}$ \\
\hline $\begin{array}{l}\text { Chapter Three } \\
\text { THE TRADITIONAL } \\
\text { VIEW OF SCIENCE } \\
\text { Recognizing the Myths } \\
\text { (8,956 words) }\end{array}$ & $\begin{array}{l}\text { After more generally describing (in chapter two) issues regarding } \\
\text { views about science promoted in science education, Professor Hodson } \\
\text { here begins to explore in greater depth particular problems with } \\
\text { students' conceptions about HPSS. In this chapter, he pays special } \\
\text { attention to issues pertaining to (reciprocal) relationships between } \\
\text { phenomena of the world and people's conceptions (representations) } \\
\text { of them. This is a key discussion, one that underlies much of what he } \\
\text { discusses in the rest of the book. For him, observations (leading to } \\
\text { data and evidence) are theory-dependent. Consequently, the science } \\
\text { that people conduct can only occur within the context of theoretical } \\
\text { structures available to them. Quoting from Barlex and Carre (1985), } \\
\text { "[w]e don't see things as they are, we see things as we are" (cited on } \\
\text { p. 46). He makes this argument in many ways, using various } \\
\text { examples. This enables him to take a stance on an important issue in } \\
\text { science education; that being the tendency of educators to place } \\
\text { students in positions that might suggest to them that science proceeds } \\
\text { via induction - a view that he claims is mythical. In his view, } \\
\text { students need to be explicitly taught theoretical conceptions enabling } \\
\text { them to make sophisticated observations, rather than be expected to } \\
\text { discover them. With this in mind, he points out that the distinction } \\
\text { between observation and inference may not always be as clear as } \\
\text { often is suggested in educational research and publication. }\end{array}$ \\
\hline $\begin{array}{l}\text { Chapter Four } \\
\text { EXPLORING } \\
\text { ALTERNATIVE } \\
\text { VIEWS OF } \\
\text { SCIENCE } \\
\text { The Ideas of Popper, } \\
\text { Lakatos and Kuhn } \\
\text { (8,825 words) }\end{array}$ & $\begin{array}{l}\text { In this chapter, Professor Hodson explores classic confrontations in } \\
\text { HPSS involving positions attributed to Karl Popper, Imre Lakatos, } \\
\text { Thomas Kuhn and Paul Feyerabend. Broadly, these authors explored } \\
\text { issues surrounding the logical and empirical bases of knowledge } \\
\text { generation processes in the sciences, along with the truth value of } \\
\text { scientists' claims. Popper and Lakatos, generally, defended a highly } \\
\text { logical and systematic process of knowledge generation that may } \\
\text { approach certainties about phenomena, while Kuhn and Feyerabend, } \\
\text { generally, problematized these claims about science - largely in the } \\
\text { light of psychological and sociological arguments, to which Popper } \\
\text { and Lakatos tended not to refer. Professor Hodson elaborates, with } \\
\text { useful examples, each of these authors' positions. In the end, he notes }\end{array}$ \\
\hline
\end{tabular}




\begin{tabular}{|c|c|}
\hline & $\begin{array}{l}\text { that Kuhn's position suggests that theories are not, necessarily, } \\
\text { correct or even close to the truth; rather, they may be best for a } \\
\text { particular paradigm. This contrasts sharply with Popper's idea of } \\
\text { verisimilitude (approaching the truth). }\end{array}$ \\
\hline $\begin{array}{l}\text { Chapter Five } \\
\text { SCIENTIFIC } \\
\text { INQUIRY, } \\
\text { EXPERIMENT AND } \\
\text { THEORY } \\
\text { What Should We Tell } \\
\text { Our Students? } \\
\text { (9,522 words) }\end{array}$ & $\begin{array}{l}\text { Chapters } 3 \text { and } 4 \text { establish cases for various historical tensions in both } \\
\text { the nature of knowledge generation and dissemination processes and } \\
\text { with regards to the truth value of knowledge claims of the sciences. } \\
\text { Before elaborating on these issues (chapters } 6 \text { \& } 7 \text { ), Professor Hodson } \\
\text { first explores a central feature of science and science education; that } \\
\text { is, empirical inquiry - much of which is conceived of in terms of } \\
\text { experimentation. He begins by noting that 'almost all textbooks and } \\
\text { curriculum documents invest enormous faith in the capacity of } \\
\text { observation and experiment to provide reliable data for making } \\
\text { unequivocal decisions about the validity of theories" (p. 85). The } \\
\text { balance of the chapter consists of his efforts to problematize this } \\
\text { notion. He does so first by casting doubt on the validity and reliability } \\
\text { of experimentation in the sciences, drawing on his claims relating to } \\
\text { theory-data interactions from chapters } 3 \text { \& } 4 \text {. He says, for example, } \\
\text { "in gathering data to test an hypothesis, the form of the hypothesis } \\
\text { and the nature and method of data collection are dictated by the very } \\
\text { theory that is under test. In other words, theory-independent } \\
\text { experiments are impossible" (p. } 86 \text { ). He then uses his analyses of } \\
\text { experimentation in the sciences to take issue with corresponding } \\
\text { dominant practices in school science. He seriously challenges } \\
\text { assumptions surrounding 'quasi-inductive' (more properly deductive) } \\
\text { discovery-type inquiry activities (both guided and unguided) aimed at } \\
\text { teaching pre-specified knowledge claims from the sciences. } \\
\text { Associated with this concern are significant difficulties he has with } \\
\text { the so-called 'process approaches' - in which students are taught, } \\
\text { often in/as a sequence, individual science skills (e.g., control of } \\
\text { variables) as a way of enabling them to conduct their own inquiries. } \\
\text { Of particular concern to him is the issue of transferability of skills } \\
\text { among contexts - a issue that is understandable in the light of his } \\
\text { emphasis on the theory-basis of almost everything in the sciences. } \\
\text { Also problematized in this chapter are assumptions about a possible } \\
\text { algorithmic 'scientific method' and the finality of individual } \\
\text { experiments. }\end{array}$ \\
\hline $\begin{array}{l}\text { Chapter Six } \\
\text { REALISM OR } \\
\text { INSTRUMENTALIS } \\
\text { M } \\
\text { What Position for } \\
\text { School Science? }\end{array}$ & $\begin{array}{l}\text { Professor Hodson's analyses of knowledge building/dissemination } \\
\text { methods in the last chapter provide an appropriate segue into the } \\
\text { focus of this chapter; that is, on the truth value of scientists' } \\
\text { knowledge claims. An important target of his analysis here is on the } \\
\text { assumption "that there is a correct version of events and phenomena, } \\
\text { and that the application of good scientific procedures and the } \\
\text { adoption of appropriate attitudes will enable scientists to arrive at the } \\
\text { truth about the world. Philosophers of science refer to this position as }\end{array}$ \\
\hline
\end{tabular}




\begin{tabular}{|c|c|}
\hline$(9,818$ words $)$ & $\begin{array}{l}\text { naïve realism" (p. 103). This he contrasts with instrumentalism, a } \\
\text { variant of antirealism. After providing arguments for both positions, } \\
\text { he ends up supporting an intermediate perspective, that of critical } \\
\text { realism (i.e., taking realist or instrumentalist tacks, depending on the } \\
\text { circumstances). In arriving at this conclusion, he again makes ample } \\
\text { use of his earlier arguments surrounding phenomena representation } \\
\text { (e.g., theory) relationships - such as the theory-limited nature of } \\
\text { observing. A particularly interesting discussion pertains to questions } \\
\text { of the existence of unseen phenomena (e.g., electrons), access to } \\
\text { which require human-invented instrumentation. Nevertheless, despite } \\
\text { human perceptual frailties, he uses predictability successes to support } \\
\text { a more realist view of phenomena: "Even if we do reduce theoretical } \\
\text { entities to mere devices for prediction the fact still remains that } \\
\text { something causes things to behave as they do. There is 'something } \\
\text { out there'. Some things are real ..." (p. 108). He also defends } \\
\text { (critical) realism, however, with the argument that scientists' } \\
\text { motivation to seek truths may depend on whether they approach their } \\
\text { work from a realist or instrumentalist stance. }\end{array}$ \\
\hline $\begin{array}{l}\text { Chapter Seven } \\
\text { INSIGHT FROM } \\
\text { THE SOCIOLOGY } \\
\text { OF SCIENCE } \\
\text { Science is What } \\
\text { Scientists Do } \\
\text { (12,773 words) }\end{array}$ & $\begin{array}{l}\text { Although Professor Hodson alludes to them numerous times in earlier } \\
\text { chapters, it is in this lengthy chapter that he dramatically complicates } \\
\text { issues surrounding phenomena representation interactions through } \\
\text { discussions about 'non-logical' factors - like intuition, emotion, } \\
\text { culture, politics, economics, etc. - affecting decision-making in the } \\
\text { sciences. A perhaps relatively benign factor in this regard is, for } \\
\text { example, scientists' conceptions of the 'aesthetic' value of the theory. } \\
\text { He quotes Richard Feynman (1965) in this regard: "You can } \\
\text { recognize truth by its beauty and simplicity... When you get it right, } \\
\text { it is obvious that it is right" (p. 124). Perhaps associated with such } \\
\text { affective factors appears to be scientists' preference for theories that } \\
\text { had some general similarity to well-established theories; such as } \\
\text { when Copernican theory was not supported largely because of its } \\
\text { dissimilarity to Aristotelian physics. However, such factors seem } \\
\text { more benign than those relating to societal conditions - either } \\
\text { generally or in terms of effects of special interest groups. For } \\
\text { example, as Professor Hodson points out, "... phrenology (Combe, } \\
\text { 1825, 1828) was perfectly suited to the socio-political climate of } \\
\text { Victorian England ..." (p. 125). Similarly, he notes: "In the Stalinist } \\
\text { Soviet Union, Darwinian ideas underpinning evolutionary biology } \\
\text { were rejected in favour of Lysenko's theorizing about Lamarckism } \\
\text { because transmission of acquired characteristics was much more } \\
\text { compatible with Marxist views about human nature, with disastrous } \\
\text { impact on agriculture and widespread famine" (p. 125). Although } \\
\text { such social factors perhaps place inappropriate pressure on scientists, } \\
\text { arguably of much greater concern are "ways in which the } \\
\text { sociopolitical, economic and military significance of science and } \\
\text { technology lead to major concerns about control and }\end{array}$ \\
\hline
\end{tabular}




\begin{tabular}{|c|c|}
\hline & $\begin{array}{l}\text { accountability..." (p. 128). Details of such issues, as he states, are } \\
\text { beyond the scope of this book. Instead, emphasis is placed on } \\
\text { sociological issues within communities of practising scientists. For } \\
\text { example, Professor Hodson devotes considerable space in discussing } \\
\text { the merits of Merton's norms (e.g., communalism), as opposed to } \\
\text { counter-norms (e.g., particularism) proposed by Mitroff. Similarly, } \\
\text { considerable emphasis is placed on sociological studies of scientists } \\
\text { in action, such as those reported by Collins and Pinch (1993), Knorr- } \\
\text { Cetina (1995) and Latour and Woolgar (1986) - who, for example, } \\
\text { note the importance of such inscriptional devices as graphs } \\
\text { constructed in convincing ways. Nevertheless, Professor Hodson does } \\
\text { provide some elaboration on adverse effects of powerful societal } \\
\text { members on science, concluding at one point: "Science is no longer } \\
\text { the disinterested search for truth and the free and open exchange of } \\
\text { information portrayed in the school science textbook stereotype. } \\
\text { Rather, it is a highly competitive enterprise in which scientists may be } \\
\text { driven by self-interest and career building, financial inducements } \\
\text { provided by business and commerce, or by the 'political imperatives' } \\
\text { of military interests" (p. 140). }\end{array}$ \\
\hline $\begin{array}{l}\text { Chapter Eight } \\
\text { MAKING A CASE } \\
\text { FOR HISTORY OF } \\
\text { SCIENCE } \\
\text { Going Beyond Dates } \\
\text { and Anecdotes } \\
\text { (12,372 words) }\end{array}$ & $\begin{array}{l}\text { After his more philosophical and sociological analyses of the nature } \\
\text { of the sciences, as depicted in the previous chapters, Professor } \\
\text { Hodson then explores history of science (HoS) and its utility in } \\
\text { school science. Noting that different stakeholders (e.g., historians vs. } \\
\text { philosophers of science) might prefer different purposes, he provides } \\
\text { detailed argumentation, with several specific examples for each, for } \\
\text { eight possible uses of HoS; that is, for: i) for content development, ii) } \\
\text { to humanize science for students, iii) for bridging the gap between } \\
\text { students interested in the Arts and the Sciences, iv) for providing } \\
\text { insights into the nature of science and science inquiry, v) for teaching } \\
\text { about relationships amongst fields of science and technology and } \\
\text { societies and environments (STSE), vi) for multicultural and } \\
\text { antiracist education, vii) for promoting subject integration, and viii) } \\
\text { for general scientific literacy. He stresses, however, that not every } \\
\text { educator might choose all eight approaches - preferring those that } \\
\text { best match their own curriculum emphases (e.g., a focus on content } \\
\text { learning). This provides him with a segue into issues of representation } \\
\text { of phenomena (human and inanimate) in history of science. He asks } \\
\text { questions about who might benefit (e.g., scientists vs. citizens), } \\
\text { depending on whether histories are told from an internalist (e.g., } \\
\text { dealing with the logic of discovery/verification and social interactions } \\
\text { amongst scientists) or an externalist (e.g., dealing with political, } \\
\text { economic, socio-cultural factors as they affect science) perspective } \\
\text { (Ziman, 1984). Similarly, he queries the merits of emphasizing, in a } \\
\text { Kuhnian sense, 'Normal' science (e.g., with its relative predictability) } \\
\text { or 'Revolutionary' science (e.g., with its relative uncertainties, false } \\
\text { starts and biases). Finally, he tackles issues of implementation of HoS }\end{array}$ \\
\hline
\end{tabular}




\begin{tabular}{|c|c|}
\hline & $\begin{array}{l}\text { in science education, not the least of which is school systems' } \\
\text { tendency to over-emphasize teaching and learning of products of } \\
\text { science and technology. }\end{array}$ \\
\hline $\begin{array}{l}\text { Chapter Nine } \\
\text { LOOKING FOR } \\
\text { BALANCE IN THE } \\
\text { CURRICULUM } \\
\text { Essential Elements in a } \\
\text { Curriculum for Critical } \\
\text { Scientific Literacy } \\
\text { (13,227 words) }\end{array}$ & 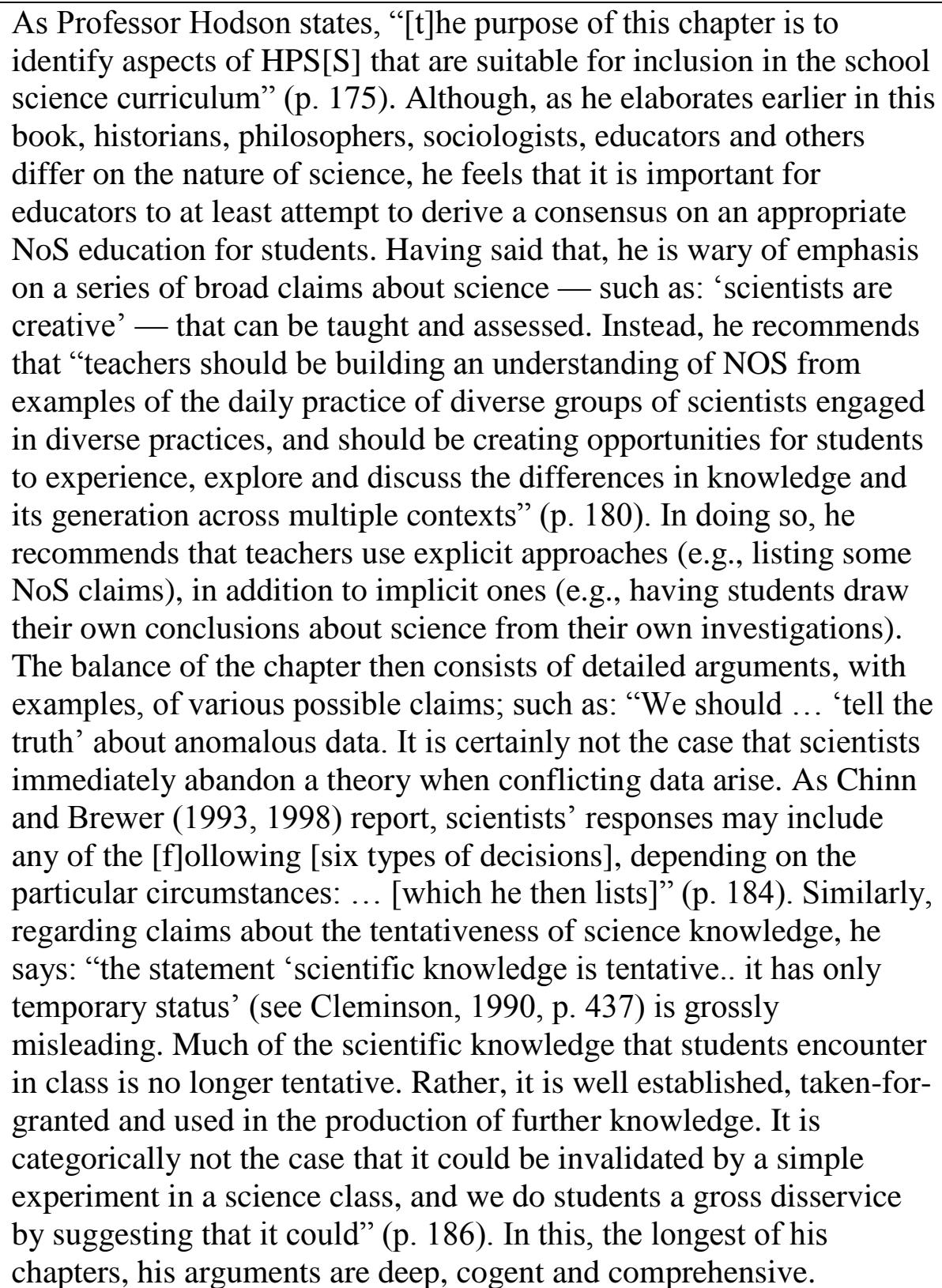 \\
\hline $\begin{array}{l}\text { Chapter Ten } \\
\text { FURTHER } \\
\text { THOUGHTS ON } \\
\text { SOCIAL } \\
\text { CONSTRUCTION } \\
\text { AND SCIENTIFIC }\end{array}$ & $\begin{array}{l}\text { In this final chapter, Professor Hodson declares that "[ } \mathrm{t}] \text { he question at } \\
\text { issue here and in the previous chapter is: what would constitute a } \\
\text { sensible balance between the view that scientific knowledge is } \\
\text { entirely independent of the social context in which it is generated and } \\
\text { the position that says all knowledge (including science) is no more } \\
\text { than a social construct?" (p. 199). Although he provides numerous } \\
\text { examples of the views supporting the latter claim, he clearly aligns } \\
\text { himself closer to the former position. He notes, for example, that }\end{array}$ \\
\hline
\end{tabular}




\begin{tabular}{|l|l|}
\hline RATIONALITY & $\begin{array}{l}\text { "...Heisenberg's Uncertainty Principle was readily accepted by } \\
\text { German physicists in the late } 1920 \text { s because it enabled them to } \\
\text { (5,429 words) }\end{array}$ \\
$\begin{array}{l}\text { repudiate, to an extent, the charge that science was overly } \\
\text { rationalistic, mechanical and deterministic and left no scope for } \\
\text { human values. But arguing that the social context created the overall } \\
\text { intellectual climate in which a particular idea was regarded as } \\
\text { acceptable is not to establish social conditions as the primary cause of } \\
\text { its acceptance. The Uncertainty Principle was accepted primarily } \\
\text { because it was an exceptionally good idea, because it solved a number } \\
\text { of long-standing problems, and because it enabled the discipline of } \\
\text { physics to make progress" (p. 201). At the same time, near the } \\
\text { chapter's end, he acknowledges pressures on scientists from } \\
\text { business/industry and the government/military: "contemporary } \\
\text { science is highly dependent on research funding, and regardless of } \\
\text { whether funds are provided by industry, the military, universities or } \\
\text { government, there is increasing pressure for research to be directed } \\
\text { towards the solving of practical problems, creating commercial } \\
\text { opportunities, establishing military advantage and meeting public } \\
\text { interest needs" (pp. 207-208). He goes on to say, "Pressures on } \\
\text { scientists can be such that they engage in misconduct and even fraud" } \\
\text { (p. 209). In the end, he suggests, "[t]eachers have important decisions } \\
\text { to make about the extent to which they will raise these kinds of issues } \\
\text { in the curriculum" (p. 209). }\end{array}$ \\
\hline
\end{tabular}

[Note to Editor and Publisher: Please fit this table to the journal as you see fit. This may involve changes in font and/or font size.]

\section{Book Characteristics}

In reviewing Professor Hodson's book, using constant comparative methods based on constructivist grounded theory (Charmaz, 2000), it became apparent to me that it can be understood in terms of a few general themes. Each of these is discussed, with examples from the book, below.

\section{Constructivism-informed}

It is clear to me that Professor Hodson supports constructivist perspectives on knowledge development and learning. In chapter three, in which he first analyzes views about science, for example, he quotes from Kant (1929, p. 22): “ 'Our empirical knowledge is a compound of that which we receive through impressions, and that which the faculty of knowledge supplies ...'" (p. 42). This leads him into a critical analysis of human conceptions of observing, induction and science progress. In the end, it is clear to me that he believes that all aspects of science - including observing, hypothesizing, experiment design/analysis, report writing, etc. — are theory-dependent. This view permeates the 
book. For example, in his chapter on use of historical case studies, he notes that history is always continually re-evaluated in the light of new theoretical perspectives (p. 165).

[insert Figure 1 about here]

His epistemological perspectives remind me of a constructivist version of knowledge duality theory; that is, that human representations of reality (e.g., knowledge claims) are in dialectical, but uncertain, relationship with phenomena of the world. This is nicely illustrated in Figure 1, a schematic taken from Roth's (2001) discussion of sciencetechnology relationships. He stresses that scientists' 'Signs' (representations, such as drawings, algorithms, etc.) may not accurately represent the 'World' (of phenomena), due to the idea of ontological gaps; that is, inconsistencies in the process of translations between ontological entities (e.g., from light, to human sense reaction, to drawing of light rays).

As a consequence of his constructivist epistemological perspectives, he recommends various constructivism-informed practices. For example, with regards to the tendency of school science systems - involving government, textbook publishers, business leaders, etc. - to prioritize quasi-inductive discovery-type inquiry activities, he counters that: "it is the science teacher's job to ensure that students perceive the world in the appropriate way - that is, the way in which currently accepted science (or the school version of it) deems appropriate" (p. 53). Similarly, when recommending explicit attention to particular claims about science, he critiques implicit strategies: "Implicit approaches, in which students are expected to acquire understanding by 'reading between the lines' as they engage in classroom activities, particularly practical work, have been shown to be, at best, only moderately successful in achieving their goals" (pp. 208-209).

\section{Historical \& Broad}

[insert Figure 2 about here]

Congruent with his lengthy, deep and productive academic career, Professor Hodson's book addresses, in a richly-illustrated way, a breadth of views about professional science. One way of comprehending this breadth is through reference to Loving's (1991) Scientific Theory Profile (STP), illustrated in Figure 2. In this profile, one can imagine teachers, philosophers, etc. holding various positions with reference to the two axes.

This book addresses a broad spectrum of views throughout the STP, with a much greater emphasis on the history and philosophy of science in the first half of the book and, afterwards, a significantly increased focus on the sociology of science. Although he does 
move back and forth, there also is a general transition from views more aligned with Rationalist-Realist positions on the STP through to more Naturalist-Antirealist positions. He begins, indirectly in his analyses of observation and induction, with reference to empiricist science - such as that of Greek scientists, including Aristotle, Thales, Eratosthenes and Ptolemy. This is followed by a discussion of the more Rationalist positions of Popper and Lakatos, which he then begins to challenge through discussions of the work of Kuhn and Feyerabend. As part of this transition, he moves from an emphasis on the internal through to the external sociology of science. For example, a more Rationalist perspective dealing with the internal sociology of science is: “... scientific knowledge has to survive rigorous critical scrutiny by members of the scientific community, who achieve consensus by employing well-characterized methods and clearly stated criteria of judgement" (p. 101). On the other hand, he deeply discusses Naturalist perspectives dealing with the external sociology of science:

Given the relationship between knowledge production and commercial, political and military power, "truth is what the powerful say it is" and those in positions of power and influence determine reality for the rest of us. It is these relationships between power and knowledge and between power and scientific practice that we should address through the politicization of the science curriculum (Hodson, 1994, 2003) (p. 193).

\section{Argumentative}

Instead of simply summarizing the range of perspectives throughout Loving's (1991) STP, Professor Hodson arranges these discussions in a way that can create cognitive dissonance in the reader. For example, as you read his account of Karl Popper's views about science, you might be convinced of the merits of falsifying hypotheses in the light of disconfirming evidence. For example, he says: "the proposition 'planets move around the Sun in elliptical orbits' is more at risk of falsification than 'planets orbit the Sun' " (p. 69). But, then, he casts doubt on claims he has just made — with statements like,

It is precisely because theories are complex structures, supported by a complex array of other theories (for example, theories of perception and theories underpinning scientific instrumentation), that an apparently falsifying observation can be deflected away from what Imre Lakatos calls the hard core of the theory (p. 72).

Arranging discussions in a way that first perhaps leads people to accept a commonly-held position (as is the case with Popper's falsificationist views), but then creates cognitive dissonance through introduction of an alternative view (e.g., Lakatos' research programmes) appears to be a pedagogical strategy based on constructivist learning principles (e.g., Osborne \& Wittrock, 1985). Learners, for example, can become more fully conscious of their pre-instructional positions (e.g., Popper) before having to confront a well-explained alternative view (e.g., Lakatos). The cognitive dissonance that is created with this confrontation can motivate conceptual change. Indeed, I remember, as a student in Professor Hodson's graduate courses, feeling 'shocked' when I suddenly had to re-think my positions on such practices as use of guided quasi-inductive inquiries in my teaching. 
Presenting alternative perspectives for most claims also appears to fit with principles of argumentation. According to Toulmin (1958), for example, scholarly arguments should contain such elements as warrants (theory) in support of claims, which also are connected to data/examples; but, as well, they should have rebuttals (counter-claims) and, related to that, claims should make appropriate use (depending on the strength of the rebuttal(s), of qualifying statements and/or adjectives and adverbs. A good example of his attention to counter-arguments can be seen in this quote:

Mitroff and Mason (1974) concluded that scientists are arranged along a continuum from extreme speculative scientists, who "wouldn't hesitate to build a whole theory of the solar system based on no data at all" (p. 1508), to data bound scientists, who "wouldn't be able to save their own hide if a fire was burning next to them because they' $d$ never have enough data to prove the fire was really there (p. 1508)" (p. 133).

\section{Forthright}

Although this book has many series of arguments and counter-arguments, Professor Hodson does not, necessarily, leave readers to guess his position. He is, indeed, quite forthright regarding his views about science, science education research and school science. Part of this is due to the clarity of his writing. He is, in my view, a wonderful writer. Reading his work is like speaking with him, and students have been enamoured with this for years. There is evidence of this personal style in his use of humour, with this quote being one of my favourites: "[Quoting one of his students,] 'How can you tell if a scientist is an extrovert? [Answer] He looks at your shoes when he is talking to you'" (emphasis added, p. 29). The ease of reading of his work also is enhanced through his use of metaphors, signposts (notes about the book's structure) and a kind-of 'spiral curriculum' (repeating points in different ways/contexts).

Congruent with his preference for deduction over induction in education, Professor Hodson is quick to declare his positions and then provide argumentative support for them. On page 2 of the book, for example, he declares:

My use of the term "universal critical scientific literacy" signals my rejection of the longstanding differentiation of science education into high status, academic/theoretical courses for those deemed (on the basis of attainment tests) to be 'high ability students' and low status courses oriented towards 'life skills' for the rest.

Similarly, in wrestling with the tension he sets up between Realists and Instrumentalists (refer, especially, to chapter 6), he declares his intermediate position: "[T]he view I wish to promote for school science is that scientists play both a realist game and an instrumentalist game, as determined by their immediate purpose: ... which some have termed critical realism" (p. 115).

In taking his particular positions, it is important to note that Professor Hodson's views often are contentious, challenging taken-for-granted assumptions about science, science education research and school science. He calmly debunks what he suggests are common 'myths' about science in school science, such as that 'science proceeds by induction' and 
that there is an algorithmic 'scientific method.' He is just as critical, however, about those who conduct research into the nature of science and then make recommendations for school science. He questions the wisdom, for example, of using broad generalizations about science for teaching and research: "[I]s this apparent consensus [achieved by some researchers] deliberately pitched at such a trivial level that nobody could possibly quibble with it?" For example, he takes issue with such statements as 'science is an attempt to explain natural phenomena,' 'scientists are creative' and 'science and technology impact each other' (p. 176). In a similar vein, he challenges the apparently simplistic claim that there are clear distinctions between observation and inference, suggesting that this represents a: "spurious claim of many science curricula" (p. 93).

\section{Recommendation}

Professor Derek Hodson's book lives up to its title: Towards scientific literacy: A teachers' guide to the history, philosophy and sociology of science. In an engaging and clear writing style, he explores - with numerous relevant examples - a broad spectrum of positions about professional science that historians, philosophers, sociologists, scientists and others have developed over the centuries. Using a constructivism-informed and argumentative style, he provides teachers, student-teachers, teacher educators and graduate school instructors with a rich source of ideas with which to fashion instructional plans that he suggests might promote universal critical (and activist) scientific literacy.

\section{References}

Bell, R. L. (2006). Perusing Pandora's box: Exploring the what, when, and how of nature of science instruction. In L. B. Flick \& N. G. Lederman (Eds.), Scientific inquiry and nature of science: Implications for teaching, learning, and teacher education (pp. 427446). Dordrecht: Springer.

Bencze, J. L. (2008). Private profit, science and science education: Critical problems and possibilities for action. Canadian Journal of Science, Mathematics \& Technology Education, 8(4), 297-312.

Charmaz, K. (2000). Grounded theory: Objectivist and constructivist methods. In N. K. Denzin \& Y. S. Lincoln (Eds.) Handbook of qualitative research (pp. 509-535). Thousand Oaks, CA: Sage.

Collins, S., Osborne, J., Ratcliffe, M., Millar, R., \& Duschl, R. (2001). What 'ideasabout-science' should be taught in school science? A Delphi study of the expert community. Paper presented at the annual conference of the American Educational Research Association, April 10-14, 2001, Seattle, WA.

Loving, C. C. (1991). The Scientific Theory Profile: A philosophy of science model for science teachers. Journal of Research in Science Teaching, 28(9), 823-838. 
McMurtry, J. (1999). The cancer stage of capitalism. London: Pluto.

Osborne, R., \& Wittrock, M. (1985). The Generative Learning Model and its implications for science education. Studies in Science Education, 12, 59-87.

Polanyi, M. (1958). Personal knowledge. London: Routledge and Kegan Paul.

Toulmin, S. (1958). The uses of argument. New York: Cambridge University Press.

White, R. T. (1996). The link between the laboratory and learning. International Journal of Science Education, 18(7), 761-774.

Ziman, J. (1984). An introduction to science studies: The philosophical and social aspects of science and technology. Cambridge: CUP. 